\title{
THE EFFECT OF WATER -STRESS ON THE MINERAL NUTRITION OF FRUIT PLANTATIONS
}

\author{
Péter Tamás Nagy - Anita Szabó - Emese Berta Szabó - Attila Illés - Ida Kincses \\ Department of Agricultural Chemistry and Soil Science, Centre for Agricultural and Applied Economic Sciences, University of Debrecen, \\ nagypt@agr.unideb.hu
}

Keywords: water-stress, climatic anomalies, fruit nutrition, nutrient uptake

SUMMARY

Besides agro-techniques the climatic conditions play an important role in agricultural production. Weather extremes are significant hazards to many horticultural regions all over the word. It has a profound influence on the growth, development and yields of a crop, incidence of pests and diseases, water needs and fertilizer requirements in terms of differences in nutrient mobilization due to water stresses. Nowadays, the weather extremes cause more and more problems and significant hazards to many horticultural regions in Hungary.

The aim of this study is to explore the problems of nutrient uptake followed from climatic anomalies and response it. In this study we focus on water supply problems (water-stress).

Reviewing the effects and nutrient disorders caused by climatic anomalies, the following statements can be taken:

- Nutrient demand of trees can be supplied only under even worse conditions.

- The most effective weapon against damage of climatic anomalies is preventative action.

- Proper choice of cultivars, species and cultivation should provide further possibilities to avoid and moderate the effects of climatic anomalies.

- Fruit growing technologies especially nutrition should be corrected and adjusted to the climatic events as modifier factors.

- The role of foliar spraying, mulching and fertigation/irrigation is increasing continuously.

- Urgent task of the near future is to correct and adjust the tested technologies of fruit growing according to these climatic events as modifier factors.

Optimal nutrient supply of trees decreases the sensitivity for unexpected climatic events. To solve these problems supplementary, foliar fertilization is recommended, which adjusted to phonological phases of trees. Moreover, mulching is regarded as an excellent water saving method.

\section{INTRODUCTION}

Climatic anomalies are significant hazards to many horticultural and viticultural regions all over the word. As the VAHAVA report states that the average of global temperature is rising and that the distribution of precipitation in time and space is undergoing a dramatic change in Hungary as well.

Theoretically, any crop can be protected from any climatic event, but economic and practical aspects limit the methods that can be used. Profitability ultimately determines whether the protection techniques can be used. An understanding and ability to minimise the risk of fruit loss or damage is fundamental to managing a profitable enterprise. Damage not only puts at risk the current season's crop, but also because of the perennial nature of fruits and grapevines, can influence the productivity of fruits and vines for several seasons in the future.

It is no doubt that frequency of unexpected climatic events and their growing rate are resulting more and more problems for fruit growers all over world. Despite of this the Hungarian growers have a very little information about the effects of climatic change (Nagyné, 2009; Nagyné et al., 2010).

It is very hard task to estimate the fruit failure which follows from climatic extremes. But its rate is growing continuously year by year. Earlier, when developing a fruit orchard, three factors should be taken into consideration: "Location, Location, Location". Nowadays this approach is not enough to realize qualified fruit growing.

Change of climatic conditions cause new tasks for today's fruit growers and scientists as well. Urgent task of the near future is to correct and adjust the tested technologies of fruit growing according to these climatic events as modifier factors. It is especially true for nutritional aspects of fruit growing technology which respond sensitively for changing of environmental conditions. The aim of this study is to explore the problems of nutrient uptake following climatic anomalies and find adequate response for them.

\section{RESULTS AND DISCUSSION}

\section{1) Disorders in nutrient uptake caused by climatic anomalies}

The quality of fruits is acquired during the development of the plant, for this reason it is necessary to know in situ the factors that influence in more or smaller degree in postharvest fruit quality. These are: the climatic factors (temperature, wind, rain, quality of air and solar light).

Considering our country, the effects of climatic factors on the fruit production zones can be evaluated upon the basis of the works of Soltész et al., (2004, 2005) and Nyéki et al., (2005). The main extreme climatic effects have been summarized by Soltész et al., (2010). 
Winter frost, spring frost, drought, sunburn, cracking and wind damage are regarded the most important climatic effects affected plantations (Soltész et al., 2008).

In this study, we focus on the effects of water-stress.

\section{2) Problems in water management}

Water supply problems in nutrient-uptake of fruit trees, like too high or even too low amount of plantavailable water-content of soils, affect significantly the quality and quantity of yield. This statement is especially valid for Hungary, because our fruit-production depends highly on the available water-amount and on its favourable distribution during the vegetation period. In the last 50 years the amount of precipitation has demonstrably reduced and its distribution has become even more unfavourable (Lakatos et al., 2005b). Regarding the amount of precipitation per each time even extremer values turn up, while sweltering heat periods occur even more often and even longer. As a result of all these factors, soil drought is getting more abundant and the ground water level is sinking on even more sites (Soltész et al., 2004; Nyéki et al., 2005; Soltész et al., 2005). Summarizing all these, it can be stated, that the water demand of fruit trees can be supplied only under even worse conditions. So irrigation plays a very important role in secure fruit production.

In the past few years, water supply problems - that are summarized in the international literature as the term of "water-stress" - have become the focal point of numerous publications. Fruit plantations, just like every plant have a physiological reaction to the anomalies in water supply.

\section{3) Effects of the lack of precipitation}

Stress reduces both water and turgor potential in fruits but stressed plants try to maintain turgor potential by osmotic adjustment. Water stress affects the turgidity pressure and osmotic potential of cells, therefore their water-uptake (Ranney et al., 1991).

The reduction in leaf water potential induces stomatal closure and increases abscisic acid levels in the leaves (Shackel et al., 1990). Stomatal closure leads to reduced photosynthesis, carbon-assimilation and transpiration, while severe stress can also affect the photochemical and enzymic reactions of photosynthesis. Shoot growth is more sensitive to water stress than crop yield. In stressed plants yield losses can be caused by reductions in inflorescence initiation, fruit set and fruit size as well as by increased fruit abscission. Yield losses are greater when stress occurs prior to the ripening stage of fruit development than during ripening. Mild stress during the ripening stage hastens the maturation processes in fruits and this leads to increases in the concentration of sugars and anthocyanin pigments and decreases in acid and $\mathrm{pH}$ levels in the fruit. Some major gaps in our knowledge of the subject of water stress are what effects stress has on respiration, translocation, hormones, mineral nutrition, physiological activity of roots, root growth and fruit quality (Nagarajah, 1989).

The decrease of water state - hydrature - of plant tissues infers partway also the dehydratation of cytoplasm. For the cytoplasm contains most of the enzymes of plant metabolism, firstly their function will be reduced. The decreased hydrature brings often respiratory problems, enhances the protein and starchdecomposition (because of the enhanced amylase activity).

The growth of the shoot is also blocked because of the small turgidity. As an effect of water stress, the default of blooming, fructification and fruit growth, just as the unfavourable ion-uptake result in the failure of the yield. This fall-out is even more expressed, if the stress comes up before, than during the ripening period. A slight ripening stress accelerates ripening procedures, therefore it increases the amount of saccharides and anthocyanine-pygments and decreases the acid-concentration of fruits.

Water stress substantially reduced fruit size and yield but had no effect on these fruit quality attributes. Water stress increased only $\mathrm{K}$ and $\mathrm{B}$ but fruit $\mathrm{Ca}$ was unaffected by any treatment. Mean dry weight of dormant spur flower buds was reduced by water stress. (Guak et al., 2001).

Not adequate water-supply, drought or even too wet circumstances affect also blooming and fruitset. Soil drought or even abundant water-supply of soil decreases the efficiency of nutrient-uptake via roots. The migration of nutrients to the radicles by diffusion or mass-flow is quite hindered in dry soils. Under unfavourable, e.g. dry soil conditions nutrient-supply is more hindered on heavy soils, than on light sandy soils. In case of persistent drought Fe-, Mn- and K-deficiency on heavy soils is related to this fact.

Unfortunately our knowledge on the effect of water-stress on the respiratory, translocation, hormonal and nutrient-supply procedures - that are closely related to the development of fruit quality - are still quite incomplete.

The effects and intensity of water-supply problems highly depend on the soil of the production site. On the sandy loam site, reduced fruit fresh weight occurred within four weeks after the imposition of water stress. Similar diameter reductions were not measured on the silt loam until five weeks after water stress initiation. Moreover, both water stress treatment and soil type affected fruit diameter and fruit weight. The seasonal pattern of fruit $\mathrm{N}$, $\mathrm{P}, \mathrm{K}, \mathrm{Ca}$ and $\mathrm{Mg}$ concentration were unaffected by the water stress treatments and soil type, decreasing from maximum early in the season, to minimum at harvest. The accumulation of $\mathrm{Ca}$ per fruit increased continuously throughout the growing season, peaking two weeks prior to harvest, and then declining at harvest. This pattern 
was unaffected by water stress or soil type. The accumulation of $\mathrm{N}, \mathrm{P}, \mathrm{K}, \mathrm{Mg}$ was continuous throughout the season, usually reaching a peak at harvest and sometimes was reduced for the water stressed apple trees grown on the sandy soil. (Yao et al., 2001)

Interestingly they came to the statement, that neither water-stress, nor soil type affect the uptake and uptake-dynamics of $\mathrm{N}-$, P-, K-, Ca- and Mg-ions.

There are relative few literature-data about the other type of water-supply problems: the high amount of precipitation that falls suddenly and causes anomalies in nutrient-supply. The even frequent occurrence of this phenomenon in Hungary as well suggests, that it's reasonable to investigate and introduce its effects on the nutrient-supply. The high - sometimes either one-month - dosage of precipitation that falls awhile affects significantly the circumstances of nutrient-uptake in the soil. This is mainly determined by the soil type. Soils with higher clay- or loam-content and higher plasticity retain more water, than sandy soils. In case of these clay and loamy soils, water-surplus or even stagnating water state may occur periodically because of the relief and/or soil texture properties.

\section{4) Effects of excessive rainfall}

The often extreme distribution of rainwater can cause unfavourable water balance situations in soils. Water-surplus has a negative effect on the oxidation-reduction processes of soils and on root respiration. The reductive circumstances in the soil induce many processes that affect the nutrient-uptake. Through the reduction transformation processes and leaching the amount of plant-available nutrient-forms decrease. Mineralization processes and root-respiration also fall back and lead to the inhibition of nutrient-uptake. Insufficient nutrientuptake may cause symptoms mentioned above. If the ground water limit lies above $150-180 \mathrm{~cm}$, or $200 \mathrm{~cm}$ under ground level, it means for tree species in Hungary a limiting soil parameter for fruit plantation.

The negative change of aerating conditions in the soil affects the root development as well. High amount of suddenly falling precipitation, too high level of ground water limit or the compression caused by cultivating machines lead to even longer water saturation state and reductive circumstances in the soil that bring root necrosis or - not very typically - shallow rooted plants on. Finally these mean a danger to tree-stability, and life-span of trees. The results of Papp and Tamási (1979) pointed out, that on a sandy soil with too high ground water level $75 \%$ of the root of four year old cv. 'Jonathan' apple trees on M4 rootstock lied shallow, in the upper $30 \mathrm{~cm}$ layer. In case of a higher yield-amount, it would cause problems in stability and nutrient-uptake.

Problems, mentioned above can be corrected by appropriate tillage, so the unfavourable soil parameters can be done away (Birkás et al., 2010; Jóri, 2010).

The extreme rainy weather in Hungary, in 2010 points out the effects of excessive rainfall to nutrition of fruit trees. The weather in Hungary in May and June 2010 was determined by two Mediterranean cyclones caused an extraordinary amount of precipitation to fall all over the country (Móring et al., 2010).

We investigated the effects of excessive precipitation as water-stress of 2010 on nutrient uptake of trees in an organic apple orchard in East-Hungary (Újfehértó). Orchard was planted in 2002, grafted on M9 rootstocks at a spacing of 5 x $1.5 \mathrm{~m}$. Monthly amounts of rainfall are presented in Table 1.

Table 1.

Monthly amount of rainfall

(Data of meteorological station of Újfehértó, 2009-2010)

\begin{tabular}{|l|c|c|c|}
\hline & $\mathbf{2 0 0 9}$ & $\mathbf{2 0 1 0}$ & \multirow{2}{*}{ Difference (\%) } \\
\hline & \multicolumn{2}{|c|}{ Precipitation (mm) } & \\
\hline január & 22,4 & 43,1 & $\mathbf{+ 9 2 , 4}$ \\
\hline február & 27 & 43,8 & $\mathbf{+ 6 2 , 2}$ \\
\hline március & 39,6 & 21,5 & $\mathbf{- 4 5 , 7}$ \\
\hline április & 12,5 & 73,9 & $\mathbf{+ 4 9 1 , 2}$ \\
\hline május & 34,9 & 172,9 & $\mathbf{+ 3 9 5 , 4}$ \\
\hline június & 90,1 & 102 & $\mathbf{+ 1 3 , 2}$ \\
\hline július & 9,9 & 148,9 & $\mathbf{+ 1 4 0 4 , 0}$ \\
\hline augusztus & 26 & 77 & $\mathbf{+ 1 9 6 , 2}$ \\
\hline szeptember & 26,7 & & \\
\hline október & 67,6 & & \\
\hline november & 69,8 & & \\
\hline december & 46,4 & & \\
\hline
\end{tabular}

Our results pointed out that the excessive, suddenly rush downing rainfall decreased the nutrient supply ability of soil, resulted reductive soil conditions and leached the mobile nutrients (Figure 1 and 2). 


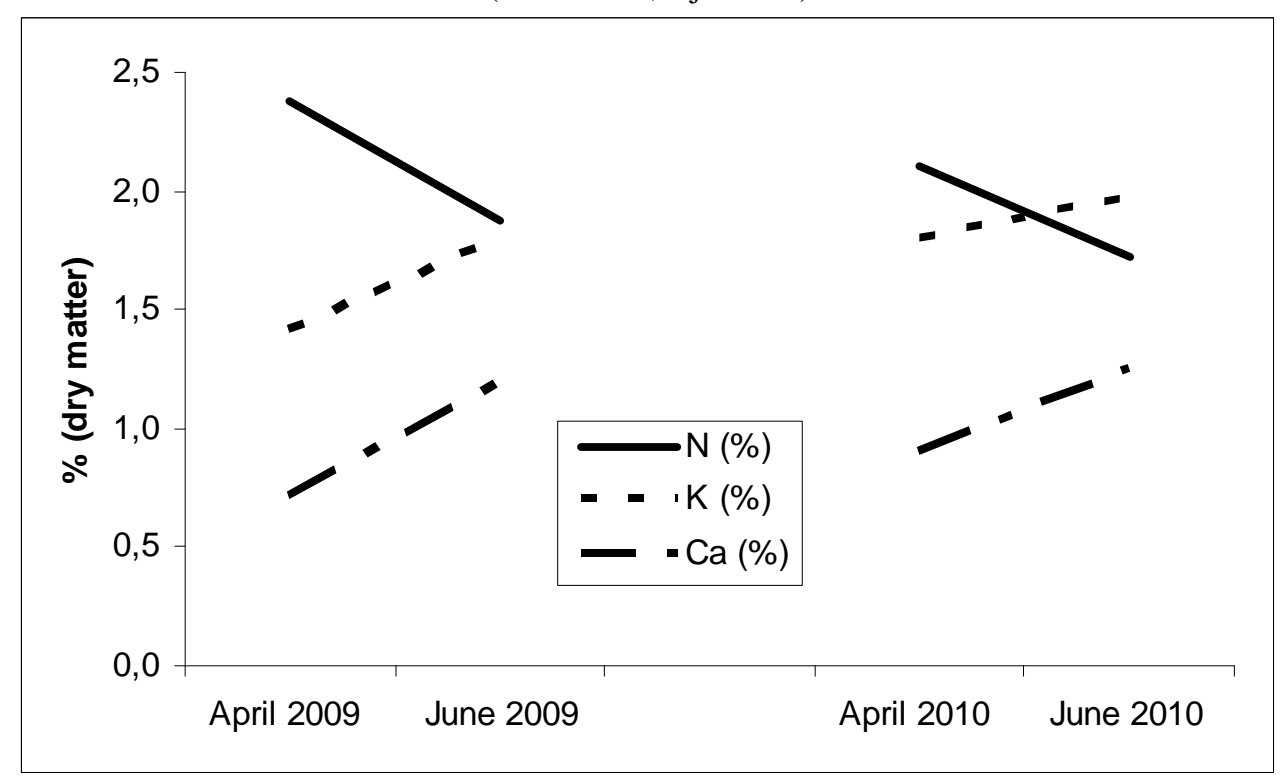

Leaf P- and Mg-content of examined apple cultivars

Figure 2. (2009-2010, Újfehértó)

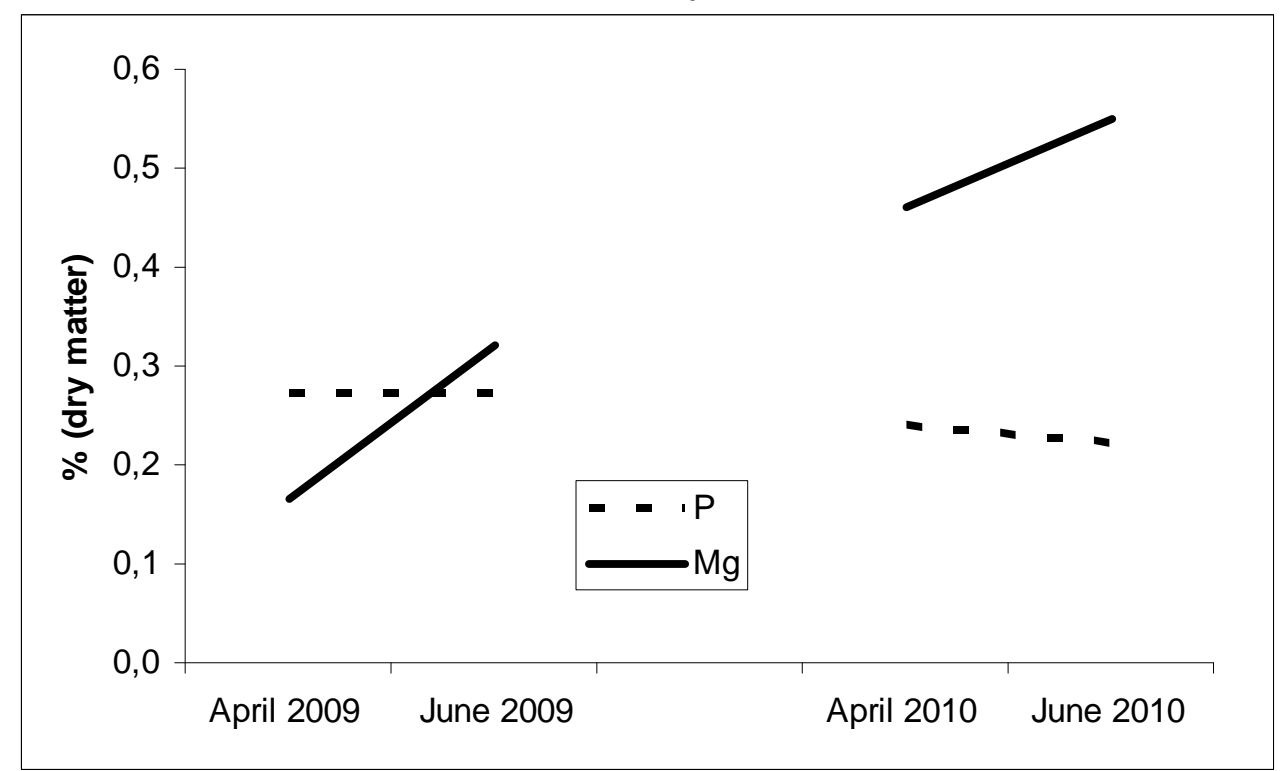

On the other hand influenced the uptake of macro and microelements by trees and shifted the nutrient ratios of trees. This effect may be increase the risk level of development of symptoms of nutritional disorders.

Disharmonious nutrient supply conditions were produced by the shifting of ratios of nutrients that can be corrected with direct and controlled nutritional treatments and planned nutritional management.

\section{5) Versions for solution}

It is still a matter, whether these effects and stresses can be avoided or corrected, and if yes, how much and by which nutrient-supply method. It can generally be stated, that plantations with adequate nutrient-supply and of good condition are more tolerant to stress. Not appropriate water-supply - both drought and surplus - results in decreasing nutrient supply, therefore in blocked growth and fruit increment. 


\section{1) Foliar fertilization}

The nutrient providing potential of soil is determined by not only the nutrient-amount, but by the soil properties, like soil texture, humus-content, permeability, soil temperature etc. In case of the not appropriate water-supply and due to that the decreased nutrient-uptake potential foliar fertilization - as a complementary nutrient-supply method - plays a very important role.

Rufat and Arbonés (2006) are found that foliar treatments are more effective under dry conditions due to the low root absorption rates from dry soils. The water-deficiency and the adequate water-supply affects mainly the Nand K-uptake - as Fallahi et al., (2006) stated.

\section{2) Groundcover management (mulching)}

Besides foliar fertilization the preservation and supplement of soil moisture might be a solution for the moderation of the effects of inadequate water-supply. In the last few decades the importance of ground covering techniques has increased owing to their application in organic farming (Skroch and Shribbs, 1986). Moreover, they are regarded as excellent water saving methods (Merwin et al., 1994).

So the importance of is intensified by the decrease of available soil moisture and frequent drought events.

Mulching has several benefits which were summarized by Merwin et al., (1994). Mulches are not only highly effective in checking evaporation and weed control, but also have influences on several processes in the soil. The benefits are variously attributed to the suppression of weed growth, to the conservation of moisture by reducing evaporation and run off, to protection from erosion, to increased infiltration of water, to the increase or decrease of soil-temperature fluctuations, to the enhancement of mineral nutrient availability, to the enhancement of nitrification, to additional nutrients and organic matter derived from a decomposing mulch, or to the preservation or improvement of soil structure. Moreover, mulching has a positive effect on nutritional and biological factors as well.

On the one hand, mulching causes an increase in the nutrient content of the soil as water leaches nutrients out of the mulch. However, the entire condition of nutrient availability may be modified for better or worse by changes induced in the moisture and temperature regimes of the soil. On the other hand, applying mulches increases root length density and brings the roots closer to the surface (Merwin and Stiles, 1994). Moreover, mulching enhances apple fruit storage quality (Lang et al., 2001).

Several publications pointed out that mulching has a positive effect on the water and temperature regimes of soil and it involves nutritional and biological factors as well.

Nowadays the number of irregular climatic anomalies is growing due to the global climatic change. It is very important that the productivity and the available nutrient supply of soil should be improved under these climatic conditions.

Based on the study of Merwin et al., (1994) and Merwin and Stiles (1994) mulching seems as an effective tool to achieve the above mentioned goals mostly in organic production systems where the possible nutritional tools are restricted and the consumer demands are high.

\section{3) Fertigation, irrigation}

The supplement of soil moisture is the other emphasized method. It is almost out of question nowadays to grow fruits up-to-date and quality oriented without irrigation and the application of irrigation systems. Soltész et al., (2005) points out, that in the region of the Hungarian Great Plain it is a burning problem to bring irrigation into effect. Similarly, the role of irrigation modelling was published in pear orchards by Nagy et al., 2010.

The volume of this paper is unfortunately too short to detail all the effects of irrigation on the yield and its quality, therefore we only mention the most important current relations.

Due to the shrinkage and the fail of the quality of subsurface water it is even more reasonable to use surface water-based irrigation (Soltész et al., 2005). It is inevitable to adopt water-sparing, but efficient irrigationsystems in the near future. The introduction of fertigation - that is already common used in West-Europe and in America - is expectant in Hungary; still its technical background is adopted on even more plantations. We shouldn't forget that fertigation and irrigation basically affects the condition nutrition-physiologic aspects of plantations. The use of not appropriate water quality may lead to cumulating soil acidity, increment of salinecontent and unbalanced nutrient-uptake. The application time, and the rationalized dosages of fertigation mean basic criteria for qualified fruit production.

Nielsen et al (2004) also have pointed out the relationships between water regime and N-uptake in their fertigation experiment. Leaf and fruit $\mathrm{N}$ increased linearly as $\mathrm{N}$ concentration of sprinkler-fertigating solution increased from low to high values. Optimum yield and highest fruit quality were associated with the medium $\mathrm{N}$ treatment. Sprinkler fertigation of $\mathrm{P}$ and $\mathrm{K}$ did not increase leaf and fruit concentration of either nutrient or meaningfully affect tree performance.

Dolega and Link (1998) also came to similar results: they didn't found any significant relationship between fertigation and fruit firmness, acidity, sugar-content, or the amount and rate of nutrients in the fruit.

Malaguti et al. (2006) found in their fertigation experiment, that the K-content of plants and soil increased as well and that fertigation affected the fruit-coloration also positive, but there couldn't be revealed any similar effect in case of $\mathrm{P}, \mathrm{Mg}, \mathrm{N}$ and the chlorophyll-content of leaves. 
They also emphasized that by fertigation a better and to the phenological phase of plants more appropriate nutrient-supply practise can be achieved. We would like to add that disturbances in nutrient-supply caused by periodic climatic anomalies can be mitigated and their effects moderated using this technology.

Although fertigation is an approved and even more common-used environment-friendly nutrient-supply method, Hornig and Bünemann (1995) realized on a newly set 'Elstar'/M9 plantation that by fertigation there are still many nutrient-supply problems to be cleared.

\section{Acknowledgements}

Thanks to OM-00265/2008 and OM-00270/2008 projects for financial assistance. Special thank to Tibor Szabó $(\mathrm{PhD})$ for the meteorological data.

\section{REFERENCES}

Birkás, M., A., Szemők, M. Mesič (2010): A klímaváltozás talajművelési, talajállapot tanulságai. „KLÍMA-21” Füzetek 61: 144-152. (In Hungarian)

Dolega, E. and Link, H. (1998): Fruit quality in relation to fertigation of apple trees. Acta Hort. 466:109-114.

Fallahi E., James R. McFerson and B. Fallahi (2006): Irrigation and Rootstocks Affect Water Use, Growth, Nutrition, Yield, and Fruit Quality of 'Fuji' and 'Gala' Apples. HortScience 41: 967-982.

Hornig, R. and Bünemann, G. (1995): Effects of soil management, irrigation and fertigation in an ip apple orchard on soil nitrate content and on tree mineral nutrition. Acta Hort. 383:339-344.

Guak S., M. Beluah, D. Nielsen and N. E. Looney (2001): Growth, fruit quality, nutrient levels, and flowering of apple trees in response to early season growth control techniques and post-harvest urea sprays. Acta Hort. 564:83-90.

Jóri, J. I. (2010): Környezetorientált talajművelési technológia (3E) és géprendszer - válasz a klímaváltozásra. „KLÍMA-21” Füzetek 61: 135-143. (In Hungarian)

Lakatos L.- Szabó Z. - Soltész M. - Nagy J. - Ertsey I. - Racskó J. - Nyéki J. (2005b): A csapadék mennyiségének, típusának és eloszlásának változása a vegetációs és nyugalmi időszakban. „AGRO-21” Füzetek 45: 53-63.

Malaguti, D., Rombola, A.D., Quartieri, M., Lucchi, A., Inderst, C., Marangoni, B. and Tagliavini, M. (2006): Effects of the rate of nutrients by fertigation and broadcast application in 'Gala' and 'Fuji' apple. Acta Hort. 721:165-172.

Merwin, I.A., and W.C. Stiles (1994): Orchard groundcover management impacts on apple tree growth and productivity, and soil nutrient availability and uptake J. Amer. Soc. Hort. Sci. 119:216-222.

Merwin, I.A., W.C. Stiles, and H.M. van Es. (1994): Orchard groundcover management impacts on soil physical properties. J. Amer. Soc. Hort. Sci. 119:209-215.

Móring, A., M. Lakatos, A. Nagy, Á. Németh (2010): A 2010. május-júniusi időjárás rendkívüliségei éghajlati szempontból. „KLÍMA-21” Füzetek 61: 3-14. (In Hungarian)

Nagarajah, S. (1989): Physiological responses of grapevines to water stress. Acta Hort. 240:249-256

Nagy, A., J. Tamás, T. Fórián, J. Nyéki, M. Soltész, Z. Szabó, (2010): Irrigation modeling in a pear orchard. International Journal of Horticultural Science 2010, 16 (3): 75-79.

Nagyné Demeter D. (2009): Egymással vagy egymás mellett? A falu. 2009. 4. 25-29p.

Nagyné Demeter D., J. Nyéki, M. Soltész, Z. Szabó (2010): Examination of the apricot variety use and the factors affecting variety use in the Gönc production area. International Journal of Horticultural Science 2010, 16 (3): 111-113.

Nyéki J. - Soltész M. - Szabó Z. - Lakatos L. -Racskó J. (2005): Felkészülés a globális klímaváltozás kedvezőtlen hatásainak kivédésére a gyümölcstermesztésben. Jelentés a VAHAVA projekt keretében végzett munkáról, MTA-KvVM, Budapest

Papp J és Tamási J. (1979): Gyümölcsösök talajművelése és tápanyagellátása. Mezőgazdasági Kiadó, Budapest.

Ranney T. G.- N. L. Bassuk and T. H. Whitlow (1991): Osmotic Adjustment and Solute Constituents in Leaves and Roots of Water-stressed Cherry (Prunus) Trees. J. Amer. Soc. Hort. Sci. 116: 684 - 688

Rufat, J. and Arbonés, A. (2006): Foliar applications of boron to almond trees in dryland areas. Acta Hort. 721:219-226.

Shackel K.A. - V. Novello and E.G. Sutter (1990): Stomatal Function and Cuticular Conductance in Whole Tissue-cultured Apple Shoots. J. Amer. Soc. Hort. Sci., 115: 468 - 472.

Skroch W.A. and Shribbs J.M., (1986): Orchard floor management: an overview. HortScience 21: 390-393.

Soltész M. - Nyéki J. - Szabó Z. (2004): A klímaváltozás kihívásai a gyümölcstermesztésben. „AGRO-21” Füzetek 34: 3-20.

Soltész M. - Nyéki J. - Szabó Z. - Gonda I. - Lakatos L. - Racskó J. - Thurzó S. - Dani M. - Drén G. (2005): Alkalmazkodási stratégia az alföldi gyümölcstermelésben a globális gazdasági és klímaváltozás nyomán. „AGRO-21” Füzetek 45:16-26.

Soltész M. - Nyéki J. - Szabó Z. (2008): Gyümölcsfajta-nemesítés szerepe a globális éghajlatváltozáshoz való alkalmazkodásban. XIV. Növénynemesítési Tudományos Napok, Budapest, Összefoglalók: 45.

Soltész M. - Szabó Z. - Nyéki J. (2010): A gyümölcstermelés biztonsága. „Klíma 21” Füzetek 61: 56-71.

Yao, S., Neilsen, G.H. and Neilsen, D. (2001): Effects of water stress on growth and mineral composition of 'Gala' apple fruit. Acta Hort. $564: 449-456$. 